\title{
Contesting and Appropriating Chineseness in Sinophone Music
}

Nathanel Amar

\section{(2) OpenEdition}

\section{Journals}

Electronic version

URL: https://journals.openedition.org/chinaperspectives/10063

DOI: 10.4000/chinaperspectives. 10063

ISSN: 1996-4617

\section{Publisher}

Centre d'étude français sur la Chine contemporaine

Printed version

Date of publication: 1 June 2020

Number of pages: 3-6

ISSN: 2070-3449

\section{Electronic reference}

Nathanel Amar, "Contesting and Appropriating Chineseness in Sinophone Music", China Perspectives [Online], 2020-2 | 2020, Online since 01 June 2020, connection on 06 July 2021. URL: http:// journals.openedition.org/chinaperspectives/10063; DOI: https://doi.org/10.4000/chinaperspectives 10063 


\title{
Contesting and Appropriating Chineseness in Sinophone Music
}

\author{
NATHANEL AMAR
}

$\mathrm{T}$ he first special issue of China Perspectives on "Sinophone Musical Worlds" (2019/3) laid the theoretical foundation for a musical approach to Sinophone studies (Amar 2019). This first issue emphasised the importance of a "place-based" analysis of the global circulation of artistic creations, promoted in the field of Sinophone studies by Shu-mei Shih (2007), and in cultural studies by Yiu Fai Chow and Jeroen de Kloet (2013) as well as Marc Moskowitz (2010), among others. The articles covered a wide range of subjects, each highlighting specific modalities of circulation of sounds, affects, and identities across the Sinophone world, be it in Cantonese-speaking communities with radio broadcasts (Lam 2019), in Xinjiang with musical performances viewed as part of a systemic state policy of cultural re-education (Anderson and Byler 2019), in the Shanghai Conservatory of Music with the adaptation of Western techniques (Grenier Borel 2019), or through an appropriation of Korean pop music in Chinese TV shows (Li 2019).

In this second volume on "Sinophone Musical Worlds," the three articles focus on politics and the ambivalent notion of Chineseness in the musical sphere. Several articles in the previous volume also studied how specific Chinese identities conveyed by music revealed political issues, especially in Xinjiang, where since 2016, "Hanness" has been performed by Uyghur musicians in a state-sponsored effort to erase their identity (Anderson and Byler 2019), or in the Shanghai Conservatory, where since 2013, "Chinese characteristics" have been integrated into the internationalisation strategies of Western classical music institutions (Grenier Borel 2019). The articles in this issue underline the political uses of popular music, and how mainstream singers, amateur musicians, and underground artists engage with the "hegemonic versions of Chineseness" (Chow and De Kloet 2011: 59) vehiculated by specific musical styles. The notion of Chineseness allows the authors to expose its different and competing definitions across various Sinophone communities, echoing Gungwu Wang's question: "Does being Chinese always mean the same thing, or does it change from time to time and place to place?" (Wang 2013: 131). This special issue thus insists on the political dimension of music - through its production, consumption, and circulation - but also on the role of music as a technology of the self, as DeNora points out: "The sense of 'self' is locatable in music. Musical materials provide terms and templates for elaborating self-identity - for identity's identification" (2000:68).

These three articles analyse specific musical styles and genres that participate in the definition of a "Chinese" sound in popular music. China Wind (zhongguofeng 中國風) music, peaking in the 2000s and performed by singers from Taiwan and the People's Republic of China (PRC), circulates a popular and apparently non-controversial notion of Chineseness (see Chenyu Lin's article in this issue). Archaic Wind (gufeng 古風) music presents itself as a more traditional approach to Chinese-sounding music but was appropriated by amateur musicians on the Internet who subvert accepted notions of Chinese history and masculinity (see Wang Yiwen's article in this issue). Finally, the last article lays out in detail the censorship mechanisms for music in the PRC, which are more complex and less monolithic than usually described, and the ways artists try to circumvent the state's censorship institutions (see my article in this issue). These three articles show that music constitutes a field of power in the Sinophone world, where different actors negotiate and (re)create their own identities according to their locality or political motivation.

\section{Sinophone music and social movements}

The study of Sinophone music opens new perspectives in political studies and more precisely in social movement dynamics. As I have previously noted, the solidarity between Hong Kong and Taiwan artists gave birth to new songs supporting protests against the anti-extradition law amendment bill (antiELAB) that started in June 2019 (Amar 2019: 3). Support from many artists of the Sinophone world for the Hong Kong protests culminated in November 2019 with the organisation of a concert in Taipei's Liberty Square (Ziyou guangchang 自由廣場). During the concert, the rock band The Chairman (Dongshi zhang yuetuan 董事長樂團) performed a Taiwanese-language (Taiyu 台語) version of the protest anthem "Clory to Hong Kong" (Jyun wing gwong gwai Hoeng Gong 願榮光歸香港). ' The articulation between Taiwanese and Cantonese in the songs as well as in the slogans shouted by the audience reflects the political climate preceding the Taiwanese presidential elections of January 2020, and the fear of a replication of the Hong Kong context in Taiwan. It was therefore not surprising to see the same artists perform during the Democratic Progressive Party's (DPP, Minjindang 民進黨) presential rallies, and create new songs for the occasion, as with Dwagie's (Dazhi 大支) "Captain Taiwan" (Taiwan duizhang 台灣隊長) $)^{2}$ or Fire Ex's (Miehuoqi yuetuan 滅火器樂團) "Confident and Brave" (Zixin yonggan zan de ming 自信勇敢咱的名). ${ }^{3}$

The 2019 anti-ELAB protest movement in Hong Kong has confirmed that music constitutes an integral part of protests and a strong tool of political expression. As in other contexts, "the logics crossing the art worlds (Becker 2008) have a great deal of similarities to those unfolded in contentious mobilisations ${ }^{\prime \prime 4}$ (Balasinski and Mathieu 2006: 11). Artists show a special

1. See the live recording of the Taiwanese version by The Chairman during the concert: https://youtu. be/Xllgpblksmc (accessed on 13 April 2020).

2. See the music video: https://youtu.be/5govBXcylVA (accessed on 13 April 2020).

3. See the music video: https://youtu.be/p-R9UqYCcYI (accessed on 13 April 2020).

4. Translated from the French by the author. 
aptitude for mobilising symbols, which "predisposes them to play a leading role in the symbolic struggles that are also, and inevitably, social and political struggles" (ibid.: 12). During rallies of the Hong Kong anti-ELAB movement, for instance, the protesters sang many songs in support of the movement. As Ron Eyerman noted in the American context, "Collective song also affords strength and courage during trying situations, such as confrontation with the authorities, or violent clashes with opponents" (Eyerman 2019: 26). Besides, "music [can] provide an important vehicle for the diffusion of movement ideas into the broader culture" (Eyerman and Jamison 1998: 1), and is a ritual performance that "can empower, help create collective identity and a sense of movement in an emotional and almost physical sense" (ibid.: 35). Interestingly, musical performances originating in the PRC during the 1989 Tiananmen movement (Schechner 1995) were later re-appropriated by the Hong Kong democratic movement, which has famously ritualised the act of singing every year during the Tiananmen Vigil at Victoria Park (Lai 2018). Local Cantonese music was by contrast a major part of past protests in Hong Kong, for instance during the 2010 Anti-Express Rail Link movement, when participants sang "Boundless Oceans, Vast Skies" (Hoi fut tin hung 海闊天空) by the Hong Kong rock band Beyond (Gao 2010) - something that was subsequently criticised during the Umbrella movement of 2014 as "ineffective" (Lai 2018: 70). The same song was nonetheless recently reinterpreted by the Malaysian rapper Namewee (Huang Mingzhi 黄明 志) in Mandarin in support of the Hong Kong protests, stirring controversy among PRC netizens. ${ }^{5}$ The anti-ELAB movement has provided new songs and singing rituals: "Clory to Hong Kong," by the anonymous composer "thomas dgx yhl" in August 2019, dubbed the "unofficial anthem of Hong Kong," was collectively sung during protests, in football stadiums, and in shopping malls - competing at times with pro-Beijing protesters singing the Chinese national anthem, the "March of the Volunteers" (Yiyongjun jinxingqu 義勇軍進行曲), in Mandarin. The creation of this new "anthem" shows how rituals and musical traditions are constantly (re)invented according to political and social contexts, and how collective identities are constructed and negotiated through music.

\section{Sinophone music and the (re)invention of tradition}

According to Eyerman and Jamison, tradition is a key component of artistic creation - a tradition that is not defined as monolithic and immutable, but "can be considered as a kind of grammar, or basic language, within which a particular song or piece of music is constructed" (1998: 29). Tradition, "both real and imagined at the same time" (ibid.: 30), participates in what Benedict Anderson has referred to as an "imagined community" (Anderson 2016), which is mobilised to create a collective identity, such as "the sense of community of working-class neighbourhoods, for example, [which] took the form, in some part, of a reconstruction of tradition" (Giddens 1994: 95). As pointed out by Raymond Williams, "'Tradition' has been commonly understood as a relatively inert, historicized segment of a social structure: tradition as the surviving past" (1977: 115), while in fact, as claimed by Eric Hobsbawm (1983), traditions are most of the time invented to serve a political or historical purpose. Here, the purpose of mobilising the notion of "tradition" in music is to understand what kinds of meanings the actors attribute to songs that can appear at first conservative or reactionary.

In the case of Sinophone music, tradition, or to be exact its invention, has been mobilised by various actors at different times. For instance, the Chinese Communist Party used the Han folkloric tradition of yangge 种歌 performances for political purposes, and these dances later spread through
Sinophone leftist communities worldwide during the Cold War (Wilcox 2020). Many scholars have studied the use of specific Chinese musical elements in foreign-influenced genres, particularly for Chinese rock since the 1980s: "The guzheng 古箏 in Cui Jian's 崔健 songs, the reference back to dynastic times in Tang Dynasty 唐朝, the Beijing-like singing voice of Qiu Ye 秋野 in the music of the band Zi Yue 子曰, the gender-bending performances that bring to mind the Beijing opera of Second Hand Rose 二手玫瑰, the ethnic style of Mongolian rockers Hanggai 杭蓋, and the appropriations of the communist past by Cui Jian" (De Kloet and Fung 2017: 78). But this constant reference to ancient musical traditions also has different meanings: according to De Kloet and Fung, for instance, it allows rock bands to not be labelled mere copycats of Western music genres. In the case of the rock band Second Hand Rose, there are clear musical and aesthetic references to Northeast Chinese opera, but the singer Liang Long 梁龍 (see cover picture) constantly subverts from within the obvious traditional Chinese elements by cross-dressing and playing with his gender assignment. On the opposite side, other bands clearly refuse to incorporate Chinese elements as a political statement. The Beijing punk band 69 makes fun of "Chinese" rock bands and of the constant reference to "Chinese characteristics" by the Communist Party in "Rock ' $n$ ' Roll with Chinese Characteristics" (You Zhongguo tese de Rock ' $n$ ' Roll 有中國特色的 Rock ' $n$ ' Roll),' while the Wuhan punk band SMZB (Shengming zhi bing 生命之餅) asks "Do you like Chinese music?" in an eponymous song - ironically using the orchestration of "American Music" by Violent Femmes - before responding "I don't like Chinese music," and immediately linking the previous question with politics by asking the audience: "Do you like chairman Jiang Zemin?"8

\section{Sinophone music and the politics of Chineseness}

The question of the incorporation of Chinese elements in music echoes debates on the notion of Chineseness raised mainly by literary scholars since the 1990s. Chineseness, understood as common features "shared by ethnic Chinese on the basis of discrete traits and traditions" (Chun 1996: 113), has been thoroughly analysed and deconstructed. While the notion of Chineseness supposes an "authentic, authoritative, and uncontested standard for all things Chinese" (Ang 1998: 225), many scholars have shown the multiplicities of Chinese identities - within the PRC, but also in Taiwan, Hong Kong, Singapore, and in diaspora communities - which cannot be located in the same physical or political space. As len Ang puts it:

Chineseness should not be seen as a fixed racial and ethnic category, but as an open and indeterminate signifier whose meanings are constantly renegotiated and rearticulated in different sections of the Chinese diaspora. That is to say, what it means to be Chinese varies from place to place, moulded by the local circumstances in which peoples of Chinese ancestry have settled and constructed new ways of living. There are, in other words, many different Chinese identities, not one. (Ang 1994a: 73)

5. "Malaysian Rapper Rapped by Chinese Netizens," The Star, 22 April 2020, https://www.thestar. com.my/news/nation/2020/04/22/malaysian-rapper-rapped-by-chinese-netizens (accessed on 23 April 2020).

6. Daniel Victor, "Hong Kong Protesters, Without an Anthem to Sing, Create One Online," The New York Times, 12 September 2019, https://www.nytimes.com/2019/09/12/world/asia/glory-tohong-kong-anthem.html (accessed on 13 April 2020).

7. 69. 1999. “有中國特色的 Rock 'n' Roll" (You Zhongguo tese de Rock ' $n$ ' Roll, Rock 'n' Roll with Chinese Characteristics), track 6 on 無聊軍隊 Wuliao jundui, Scream Records (PRC) [Compact Disc].

8. SMZB. 2001. "Do You Like Chinese Music," track 1 on Wuhan Punk, Nasty Vinyl (Germany) [Vinyl 7]. 
Chineseness, as a historical construct, has always been a political project, used by different political forces throughout history. Allen Chun noticed different interpretations of Chineseness according to different political contexts: in Taiwan, where "the Kuomintang 國民黨 (KMT), or Nationalist, regime on Taiwan has, on the whole, depicted itself as the guardian of traditional Chinese culture" (Chun 1996: 116), while the PRC, after the Cultural Revolution and its apparent rejection of traditional thought and practices, has politicised Chinese culture and historical knowledge "as an important tool in China's search for its cultural roots and in political legitimacy as a nation" (ibid.: 118).

Since December 2019, the COVID-19 outbreak has shown how Sinophone singers are mobilised by the PRC state apparatus to promote a noncontroversial vision of the measures implemented to contain the virus, while popular reaction, mainly in Taiwan and Hong Kong, has undermined the PRC's effort to exploit musical Chineseness as a way to unify the Sinophone world. A controversy broke out in April 2020 when Hong Kong Cantopop star Eason Chan 陳奕迅 and Taiwanese Mandopop star Jolin Tsai 蔡依林 released in English "Fight as One," ${ }^{19}$ a title in line with previous charity songs such as "Hand in Hand" (Shou gian shou 手率手), produced in Taiwan in 2003 during the SARS outbreak by the Taiwanese-American singer Wang Leehom 王力宏, and featuring Jolin Tsai, among others. "Fight as One" was heavily criticised for being produced by Yunnan Radio and Television (Yunnan guangbo dianshi tai 雲南廣播電視台), and for featuring children holding hand-painted drawings thanking China for its support in the music video. ${ }^{10}$ The song indeed recalls previous PRC government-sponsored singles using Sinophone pop-stars from Taiwan, Hong Kong, or Singapore to promote international events taking place in China such as the Beijing 2008 Olympic Games or the 2010 Shanghai International Expo. While Chinese rappers and Singaporean pop-stars have produced songs praising China's frontline medical staff, ${ }_{11}^{11}$ others instead criticised the late response to the virus outbreak by the PRC government and international organisations, as did the Taiwanese rapper Dwagie in his song "WHO."12

Each context thus produces specific politics of Chineseness in the Sinophone world, involving and reshaping musical creation. Chen-yu Lin argues in the first article of this special issue, entitled "Relocating the Functions of Chineseness in Chinese Popular Music after the China Wind," that one of the major attempts to relocate Chineseness in popular music was embodied by the Taiwanese pop-star Jay Chou 周杰倫 and the TaiwaneseAmerican Wang Leehom. These two singers epitomise the China Wind musical trend that dominated the Sinophone world in the 2000s, by integrating instruments and rhythms considered typically Chinese. Yiu Fai Chow and Jeroen De Kloet note that China Wind was also relocated and feminised, as a way to question the dominating male voice, in Hong Kong, Malaysia, and Singapore, thus contesting "who has the authority to speak as Chinese, to define Chinese" (Chow and De Kloet 2013: 78). In her article, Chen-yu Lin argues that recent reality TV shows such as The Voice of China (Zhongguo hao shengyin 中國好聲音) produced in the PRC have successfully coopted China Wind for nationalistic and capitalist purposes, subsuming the contestants' diverse nationalities into one fantasised Chinese identity. Looking at the latest works of both Jay Chou and Wang Leehom, the author shows how China Wind is considered a product made for the globalised market, shaped by politics, state censorship, capitalism, and identities.

In the second article of this special issue, entitled "Homoeroticising Archaic Wind Music: A Rhizomatic Return to Ancient China," Wang Yiwen tackles a more recent musical genre, partly derived from China Wind, and called Archaic Wind music. Archaic Wind music is characterised by symbolic references to ancient China in its lyrics or melodies, but as the author argues, the appropriation of this music by individuals and amateurs on streaming platforms deconstructs these obvious traditional roots. As Howard Becker once wrote to the musicologist and folklorist Charles Seeger - father of the folk singer and social activist Pete Seeger - sociologists should not be "interested in 'decoding' art works, in finding the work's secret meanings as reflections of society. They prefer to see those works as the result of what a lot of people have done jointly" (Becker 1989: 282). The purpose of this article is indeed to show how people appropriate Chineseness and Archaic Wind to create new layers of meaning, and more specifically how homoerotic themes emerge from minor uses of traditional music on the Internet. Contrary to Tu Wei-ming, who sees "Cultural China" as a "living tree" (1993) composed of a unique root and several branches, Wang Yiwen shows how Chineseness, in the context of Archaic Wind, functions as a rhizome that subverts the stereotypical understanding of what it means to be Chinese.

In the final article of this issue, "Navigating and Circumventing (Self) Censorship in the Chinese Music Scene," I take a closer look at the PRC cultural institutions to understand how artists cope with a censorship based on the state's notion of acceptable Chineseness, and how they sometimes succeed in circumventing its mechanisms. Resisting monolithic conceptions of PRC official institutions, this article details the historical trajectory of the censorship apparatus in the PRC and points out the fluidity of censorship, especially in the context of internal competition between various government branches and marketisation of the music industry. Based on ethnographic fieldwork in the rock and punk community, I show how, in the case of artists and labels unaffiliated with state institutions, their knowhow and tactics allow them to produce an album or perform in a live venue. Musical censorship in the PRC has implications for the greater Sinophone world: for instance, 3,000 of the Hong Kong lyricist Albert Leung's 林夕 songs have been removed from the Chinese Internet since his participation in the concert in support of the Hong Kong anti-ELAB movement in Taipei. ${ }^{13}$ Censorship also underlines acts of Sinophone solidarity: to protest the disappearance of the folk singer Li Zhi 李志 since April 2019, organisers of the Hong Kong Tiananmen vigil at Victoria Park broadcasted two of his songs during the ceremony on 4 June 2019.

This second volume on "Sinophone Musical Worlds" therefore offers a closer look at the politics of Chineseness in the music world. Articulating Sinophone studies and music studies from an interdisciplinary perspective allows us to understand global circulation of music in the Sinophone world, how identities are constructed and reworked from within, as well as the political role of the music world. Chineseness and politics are inextricably bound together; as len Ang famously said, "If I am inescapably Chinese by descent, I am only sometimes Chinese by consent. When and how is a matter of politics" (Ang 1994b: 18).

9. See the music video: https://youtu.be/LmO2HNXKq_g (accessed on 13 April 2020).

10. Kendra Tan, "Why Are Netizens Hating On Eason Chan and Jolin Tsai's COVID-19 Song Collaboration?," Today Online, 8 April 2020, https://www.todayonline.com/8days/ sceneandheard/entertainment/why-are-netizens-hating-eason-chan-and-jolin-tsais-covid-19song (accessed on 13 April 2020).

11. Lee Wei Lin, "JJ Lin, Stefanie Sun release song dedicated to those working on the frontlines against Wuhan virus," 8 Days, 29 January 2020, https://www.8days.sg/sceneandheard/entertainment/jjlin-stefanie-sun-release-song-dedicated-to-those-working-on-12364514 (accessed on 13 April 2020).

12. On the World Health Organisation, see the music video: https://youtu.be/yVuelwld3dU (accessed on 13 April 2020).

13. “林夕逾3000作品被消失” (Lin Xi yu 3000 zuopin bei xiaoshi, More than 3,000 songs of Albert Leung have disappeared), Apple Daily, 23 November 2019: https://hk.appledaily.com/ entertainment/20191123/OWG2DX7273Z4F67QKDCV7FJLHE/ (accessed on 13 April 2020). 


\section{Acknowledgements}

The editor would like to thank the editorial team at the CEFC for their dedicated support and precious help during the editing process of these two volumes on "Sinophone Musical Worlds," as well as the contributing authors and the reviewers for their work on these two special issues.
I Dr. Nathanel Amar is a Researcher and the Director of the CEFC Taipei office. Room B110, Research Center for Humanities and Social Sciences, Academia Sinica, Taipei 11529, Taiwan (namar@cefc.com.hk).

\section{References}

AMAR, Nathanel. 2019. "Editorial - Including Music in the Sinophone, Provincializing Chinese Music." China Perspectives 3(118): 3-6.

ANG, len. 1994a. "The Differential Politics of Chineseness." Southeast Asian Journal of Social Science 22: 72-9.

ANG, len. 1994b. "On Not Speaking Chinese: Postmodern Ethnicity and the Politics of Diaspora." New Formations 24: 1-18.

ANG, len. 1998. "Can One Say No to Chineseness? Pushing the Limits of the Diasporic Paradigm." boundary 2 25(3): 223-42.

ANDERSON, Amy, and Darren BYLER. 2019. "'Eating Hanness': Uyghur Musical Tradition in a Time of Re-education." China Perspectives 3(118): 17-26.

ANDERSON, Benedict. 2016. Imagined Communities. Reflection on the Origin and Spread of Nationalism. London:Verso.

BALASINSKI, Justyne, and Lilian MATHIEU. 2015. "Introduction: la contestation dans l'art, l'art dans la contestation" (Introduction: Contention in Art, Art in Contention). In Justyne Balasinski and Lilian Mathieu (eds.), Art et contestation (Art and Contention). Rennes: Presses Universitaires de Rennes. 9-28.

BECKER, Howard. 2008. Art Worlds. Berkeley: University of California Press.

BECKER, Howard. 1989. "Ethnomusicology and Sociology: A Letter to Charles Seeger." Ethnomusicology 33: 275-85.

CHOW, Yiu Fai, and Jeroen DE KLOET. 2011. "Blowing in the China Wind: Engagements with Chinesness in Hong Kong's Zhongguofeng Music Videos." Visual Anthropology 24: 59-76.

CHOW, Yiu Fai, and Jeroen DE KLOET. 2013. Sonic Multiplicities. Hong Kong Pop and the Global Circulation of Sound and Image. Chicago: Intellect.

CHUN, Allen. 1996. "Fuck Chineseness: On the Ambiguities of Ethnicity as Culture as Identity." boundary 2 23(2): 111-38.

DE KLOET Jeroen, and Anthony FUNG. 2017. Youth Cultures in China. Cambridge: Polity.

EYERMAN, Ron. 2019. "La musique contestataire à l'ère de Donald Trump" (Protest Music in the Age of Trump). In Violaine Roussel (ed.), Art et contestation aux États-Unis (Art and Contention in the United States). Paris: Presses Universitaires de France. 25-42.

EYERMAN, Ron, and Andrew JAMISON. 1998. Music and Social Movements. Mobilizing Traditions in the Twentieth Century. Cambridge: Cambridge University Press.
GAO, Yujuan 高玉娟. 2010. “社會運動為甚麼要唱 Beyond 的 歌? Beyond 所體現的搖滾原真性及社群力量” (Shehui yundong weishenme yao chang Beyond de ge? Beyond suo tixian de yaogun yuanzhenxing ji shequn liliang, Why does the social movement sings Beyond's songs? Rock authenticity and community power embodied by Beyond). Hong Kong: Lingnan University, Master of Cultural Studies. https://www.In.edu.hk/mcsln/21th_issue/pdf/feature_03.pdf (accessed on 13 April 2020).

CIDDENS, Anthony. 1994. "Living in a Post-Traditional Society." In Ulrich Beck, Scott Lash, and Anthony Gidden (eds.), Reflexive Modernization. Politics, Tradition and Aesthetics in the Modern Social Order. Cambridge: Cambridge University Press. 56-109.

GRENIER BOREL, Eugénie. 2019. "The Shanghai Conservatory of Music and its Rhetoric: Building a World Class Musical Institution with Chinese Characteristics." China Perspectives 3(118): 27-36.

HOBSBAWM, Eric. 1983. "Introduction: Inventing Traditions." In Eric Hobsbawm and Terence Ranger (eds.), The Invention of Tradition. Cambridge: Cambridge University Press.

LAI, Winnie. 2018. "'Happy Birthday to You': Music as Nonviolent Weapon in the Umbrella Movement." Hong Kong Studies 1(1):66-82.

LAM, Nga Li. 2019. "'The Song of Selling Olives': Acoustic Experience and Cantonese Identity in Canton, Hong Kong, and Macau across the Great Divide of 1949." China Perspectives 3(118): 9-16.

LI, Tian. 2019. "'Bang Bang Bang' - Nonsense or an Alternative Language? The Lingualscape in the Chinese Remake of I Am a Singer." China Perspectives 3(118): 37-46.

MOSKOWITZ, Marc L. 2010. Cries of Joy, Songs of Sorrow. Chinese Pop Music and Its Cultural Connotations. Hawai' i: University of Hawai'i Press.

SCHECHNER, Richard. 1995. The Future of Ritual. Writings on Culture and Performance. Abington-On-Thames: Routledge.

TU, Wei-ming (eds.). 1993. The Living Tree. The Changing Meaning of Being Chinese Today. Palo Alto: Stanford University Press.

WANG, Gungwu. 2013. "Chineseness. The Dilemmas of Place and Practice." In Shu-mei Shih, Chien-hsin Tsai, and Brian Bernards (eds.), Sinophone Studies. A Critical Reader. New York: Columbia University Press. 121-44.

WILCOX, Emily. 2020. "When Folk Dance Was Radical: Cold War Yangge, World Youth Festivals, and Overseas Chinese Leftist Culture in the 1950s and 1960s." China Perspectives 1(120): 33-42.

WILLIAMS, Raymond. 1977. Marxism and Literature. Oxford: Oxford University Press. 